\title{
16 B. S. Johnson, The Unfortunates (1969)
}

\begin{abstract}
The chapter discusses The Unfortunates as arguably the central example of an experimental strain in 1960s British writing, characteristic of Johnson's role as the most outspoken critic of what he regarded as the pointlessly anachronistic mainstream of predominantly realist fiction. The novel is also characteristic of Johnson's œuvre in that it follows his highly idiosyncratic insistence that 'fiction is lying' and that the only reasonable task for the novel is the truthful, autobiographical representation of thought processes. All the novel's central concerns - cancer, memory, and urban topographies - are characterized by non-linearity and resistance to representation in conventional fiction. The text thus continues Johnson's preoccupation with the materiality of the book and comes in 27 separately bound sections which, apart from those marked "First" and "Last", are unnumbered, inviting readers to read them in any order, thus suggesting the random nature of memory, disease and life in general.
\end{abstract}

Keywords: Autobiography, experimentalism, memory, metafiction, truth

\section{Context: Author, Guvre, Moment}

The Unfortunates (1969) is in more than one sense the central novel of an author once celebrated for his radical innovations, an author who is now - despite a modest revival of interest since the late 1990s - hardly known outside a coterie of scholars interested in a distinctly experimental tradition of twentieth-century British writing. It is the fourth of B. S. Johnson's seven novels published between 1963 and 1975, but it can also be regarded as his most innovative and thought-provoking work.

Born to a working-class family in London in 1933 and forced to work as a book-keeping clerk in the early 1950s, from 1956 to 1959 Johnson was a mature student of English at King's College, London, on a scholarship and, with few interruptions, such as a brief residence as the Gregynog Arts Fellow at the University of Wales in Aberystwyth in 1970, he spent almost his entire life in London. For most of his creative life, he worked as a supply teacher, sports commentator and journalist, because, despite his notoriety as a writer, his extensive media presence and a number of grants and scholarships, he was never able to make a living for himself - let alone his family - from his literary writing alone. Despite these bread-and-butter jobs, in a career spanning little more than ten years, he was remarkably productive as a novelist, dramatist, poet, filmmaker, editor and writer for radio and television, even winning several awards at international film festivals for his short films (Tew 2001, 4). Moreover, he frequently 
appeared on television and was highly visible as an outspoken, often opinionated writer and public intellectual with clearly leftist sympathies, who more than once attacked what he regarded as the "stultifyingly philistine [...] general book culture of [his] country" (Johnson 1985b [1973], 13; for informative surveys of his output and career, cf. Tew 2001, 3-70; Coe 2004, 13-31; for a brief discussion of Johnson's poetry, cf. Garrett 1985).

All his seven novels are formally innovative in a vein that might, in shorthand, be designated as that extending from Laurence Sterne to Joyce, Beckett and the nouveau roman. Johnson's first novel Travelling People (1963) already employed different registers and styles (passages in a pastiche of eighteenth-century English, letters, journal entries, interior monologues, film script) as well as typographical ploys like grey and black pages lifted more or less directly from Tristram Shandy (1759-1767). It is the only novel he did not allow to be reprinted, because he quickly came to dismiss its mixture of "part truth and part fiction" (Johnson 1985 [1973], 9) as no longer suiting his conviction that "truth" - largely understood as autobiographical truth - had to be the ultimate aim of writing.

In keeping with this credo, Albert Angelo (1964) uses the unsuccessful architect Albert Angelo and his experience of making a living by supply teaching at a disadvantaged school in London to record Johnson's own experience as a struggling young writer forced to support himself in the same way. This novel was notorious for the holes cut into selected pages to allow for glimpses forward to a later page as well as for the arrangement of parallel columns for some 30 pages to suggest the simultaneity of the pupils' talk on the one hand and their teacher's thoughts on the other (cf. Johnson 2004, Albert Angelo 66-99). Finally, Albert Angelo is known for the metaleptic authorial intrusion near the end, which points to its autobiographical nature and its truth claim: "fuck all this lying look what im really trying to write about is writing not all this stuff about architecture trying to say something about writing about my writing [...] im trying to say something about me through him albert an architect when whats the point in covering up" (Johnson 2004, Albert Angelo 167).

His third novel, Trawl (1966), is a narrowly autobiographical account, entirely in interior monologue, of time spent on a fishing boat a few years earlier, which uses the metaphor of trawling to suggest how the mind drags up memories from the unconscious; the novel again uses typographical ploys, here especially various lengths of blank spaces, to suggest breaks and pauses in thought processes.

The Unfortunates (1969), which is here selected for more detailed discussion, is essentially the interior monologue of a narrator (recognizably, even demonstratively B.S. Johnson himself) who has been sent to an unnamed city (identifiable as Nottingham) to report a football match for the Observer (the report, "Sub Inspires City Triumph: City 1 United 0; From B. S. Johnson”, is reproduced on the inside of the box). It is only when he sees the train station and its surroundings that he realizes that this is a place he knows well. It is here that one of his closest friends during his early career as a writer, Tony Tillinghast, a promising literary scholar and an expert on 
James Boswell, lived before he died of cancer at the age of 29 in 1964, leaving behind his wife and infant son. The novel, covering some eight hours the narrator spends in the city, superficially recounts his itinerary through the city, but mainly uses locations encountered along the way as triggers for memories. Appearing in apparently random, associative order, these are interwoven memories of Tony and the city, recollections of walks taken together or of evenings spent in pubs, of visits to the city with a much-loved former girlfriend who was later to betray him, but also of Tony's illness and death, all of these memories triggered by topographical details and locations associated with Tony. The book, notorious as Johnson's "book in a box", consists of 27 separately bound chapters ranging from a few lines to 12 pages in length and delivered in unnumbered random sequence, with only the first and last chapters designated as such. ${ }^{1}$

The following novels, House Mother Normal and Christie Malry's Own Double-Entry leave behind the narrowly autobiographical mode while continuing the strand of metafictional experimentation. House Mother Normal (1971) is the attempt to narrate the events of one evening in a home for elderly people from nine different perspectives, eight old people - mentally and physically challenged in diverse, precisely defined ways - and the 'House Mother'. Their perceptions are exactly synchronized by allotting the same 21 pages to each perspective, leading to several entirely blank pages (inmate's name in the headline apart) when a person falls asleep, for instance. Finally, as in Albert Angelo, a metaleptic intrusion on the excess 22nd page of her account, has the house mother reveal herself as the "puppet or concoction of a writer [...] So you see this is from his skull" (Johnson 2004, House Mother Normal 204). Christie Malry's Own Double-Entry (1973), Johnson's most obviously humorous novel, is the account of a frustrated young man who transfers the principle of double-entry book-keeping he has learned as an accountant to his dealings with society at large. Thus, he offsets each perceived offense against him - from "Office Supervisor's lack of sympathy" (1985a [1973], 47) to "Socialism not given a chance” (151) - by increasingly drastic forms of recompense - from "General removal of small items of stationery" (119) to the "Death of 20,479 innocent West Londoners" by poisoning a water reservoir with cyanide (151). The corresponding balance sheets are graphically presented at the end of each of the five sections of the text. Here, the outrageous, ostentatiously unrealistic nature of Christie's responses as well as numerous metaleptic intrusions ultimately disposing both of the protagonist and of the conventions of mainstream fiction - do not allow readers for a moment to forget they are reading a novel.

1 Since simple page references are obviously impossible in the case of The Unfortunates, I follow the common practice of referring to the novel by the opening words of the section in question and the page number within the section; the "First" and "Last" sections will be referred to as such. All quotations from the novel refer to Johnson 1999 [1969]. 
Johnson's final novel, See the Old Lady Decently, completed shortly before his suicide in 1973 and posthumously published in 1975, is a tribute to Johnson's mother, who died of cancer in 1971. In formal terms, the novel makes use of an arsenal of, broadly speaking, 'experimental' devices already explored in his previous works. In contrast to the arguably narrow scope of most earlier novels, however, this text, in addition to the exploration of family history by means of documents, photographs, letters and poems, reaches out into history and myth, by referring to historical and mythical contexts and analogies - not least the decline of the British Empire. It has been called both "his most successful novel [and] most ambitious work" (Levitt 1983, 443) and "the work of a writer reaching the end of his artistic tether [...] a statement of the literary problems Johnson felt himself to be facing, rather than a bold step forward on the journey towards solving them" (Coe 2004, 30-31). Of all Johnson's novels, The Unfortunates has attracted by far the most critical attention and - as "perhaps the most extreme [one]" (Johnson 1985b [1973], 8) - lends itself to highlighting both his thematic preoccupations and his aesthetic strategies.

\section{Basic Coordinates: Central Topics and Concerns}

The novel's opening paragraphs already may be said to show the interweaving of its major concerns:

\footnotetext{
But I know this city! This green ticket-hall, the long office half-rounded at its ends, that ironic clerestory, brown glazed tiles, green below, the same, the decorative hammerbeams supporting nothing, above, of course! I know this city! How did I not realize when he said, Go and do City this week, that it was this city!

Tony. His cheeks sallowed and collapsed round the insinuated bones, the gums shrivelled, was it, or shrunken [...].

Covered courtyards, taxis, take a taxi, always take a taxi in a strange city, but no, I know this city! The mind circles, at random, does not remember, from one moment to another, other things interpose themselves, the mind's The station exits on a bridge, yes of course, and the blackened gantries rise like steel gibbets above the Midland red wall opposite. I should turn right, right, towards the city centre, yes, ah, and that pub! ("First” 1-2; gaps original).
}

The random workings of memory and its triggering by familiar architectural and topographical details of the city are central to the novel, which associatively ranges back and forth between the task of reporting the match ("Go and do City this week") and other activities of the day on the one hand and recollections of Tony and his illness, of their earlier friendship, of his death and funeral on the other. These frequently interwoven themes - held together by an overarching concern with 'truthfulness' recur throughout the novel, suggesting simultaneity and a superimposition of past and present in the mind. 


\subsection{Disease and Death}

Tony Tillinghast's illness, his death from cancer and the time spent with him and his wife June before and during his illness as recollected by the narrator clearly form the thematic backbone of the novel, a centrality emphasized by the cover image of the original 1969 edition, which showed a close-up photograph of cancer cells. The text repeatedly provides unsparingly detailed depictions of Tony's frailty and bodily disintegration as a result of the progressing cancer. The word 'cancer' itself is conspicuously absent from the text, though it is replaced by the equally obvious but less affectively loaded term 'tumour'.

Elaine Scarry has noted that "physical pain does not simply resist language but actively destroys it, bringing about an immediate reversion to a state anterior to language, to the sounds and cries a human being makes before language is learned" (qtd. in Lea 2015, 787). In keeping with this observation, it is hardly accidental that the dominant image of Tony's illness is that of his shrivelled gums and his dry mouth, suggesting a connection between his illness and the loss or impairment of speech, which corresponds to the frequently tentative, halting prose of the text (see 2.5 below as well as Lea 2015, 792).

Though the random order of the 25 middle sections makes it implausible to speak of a progressive disintegration throughout, there is a marked difference in the coherence of the text in the "First" and "Last" sections: While the four paragraphs on just over three pages in the "First" section make for a fairly coherent reading experience, the 17 sections on just over five pages of the "Last" section - with long blanks within and especially long breaks between paragraphs - do suggest incoherence and disintegration.

Tying the central concern with disease and death to the disjointed nature of the text, Daniel Lea has argued that the novel's formal disintegration and the resulting "multiplicity of readings reflects the excessive and proliferative growth" of cancer $(2015,787)$ as well as its "ability to deconstruct the hermeneutic reliability of narrative” $(2015,785)$. In a related vein, Julia Jordan suggests that the novel is designed to undercut the "curative trajectory" of narrative, that Johnson "uses his form to cancel the consolations of narrative construction" (2014, 745). This is suggested by the narrator's comment on his inability to understand and make sense of the disease:

That this thing could just come from nowhere, from inside himself, of his very self, to attack him, to put his self in danger, I still do not understand. Perhaps there is nothing to be understood, perhaps understanding is simply not to be found, is not applicable to such a thing. But it is hard, hard, not to try to understand, even for me, who accept that all is nothing, that sense does not exist. (“For recuperation” 2)

Emphasizing death as a central theme of "all of Johnson's novels" and of The Unfortunates in particular, Ronald Shustermann even suggests that "the act of putting the text back in its box at the end does seem to echo, physically, the closing of a coffin" 
(2010, 179). Persuasive as this may sound, it seems partly misleading, because it suggests precisely the kind of finality and closure which the novel's formal presentation in unbound sections seems designed to undercut. Rather, the semantic proliferation and the excessive semiosis engendered by the non-linear arrangement of the chapters and the resulting multiplication of potential connections is echoed in the metaphors of disease spreading metastatically throughout the text, "infecting" as it were, other semantic fields: "new bungalows [...] spread cankerously over the cliffs" ("For recuperation" 1).

\subsection{The Unfortunates as a Prose Elegy}

In a sympathetic survey of Johnson's novelistic output in the Spectator in 1991, Jonathan Coe spoke of The Unfortunates as "a sustained lament in the tradition of Lycidas" (for the elegiac nature of The Unfortunates, cf. also Tredell 1985, and Jordan 2014). Thus, a central impetus appears to have been the promise to his friend faithfully to record his life and his dying:

[S]o the last thing I said to him, all I had to give him, alone with him, with my coat on, about to go, the car waiting outside to run us to the station, staring down at him, facing those eyes, he staring back all the time now, it must have been a great effort for him, yes, and I said, it was all I had, what else could I do, I said, I'll get it all down, mate. It'll be very little, he said, after a while, slowly, still those eyes. That's all anyone has done, very little, I said. ("So he came to his parents" 5; gaps original)

This dovetails with one of the three unattributed quotes on the inside of the box in which the loose sections are delivered, a notion Johnson's namesake Samuel Johnson formulated in his Rambler essay on "The Dignity and Usefulness of Biography”: "I have often thought that there has rarely passed a life of which a judicious and faithful narrative would not be useful” (1969 [1750], 320). The poignant irony here lies in the fact that Tony Tillinghast was a scholar working on Samuel Johnson's biographer James Boswell (cf. "Again the house" 6; "The estate" 6; "At least once" 1) and that B.S. Johnson, as it were, came to be Tillinghast's Boswell. But if The Unfortunates can be read as a prose elegy, it also shares a further characteristic with the traditional English elegy:

[Major elegies are frequently] highly self-referential and metapoetic texts. In many elegies, this is even the dominant feature. These texts are often less about the deceased, whose memory they supposedly mean to keep alive, but rather primarily about the mourner in his specific role as a poet. (Kraushaar 2004, 12, my trans.; cf. also several readings in Sacks 1985) 
Strictly in keeping with this notion, the novel is at least as much concerned with Johnson's attempts at coming to terms with Tony's death and with his own self-positioning as a writer as it is with Tony himself (cf. also 2.5 and 3 below).

\subsection{The Nature of Memory and the Urban Palimpsest}

A further unattributed motto on the inside of the box is from Laurence Sterne's Tristram Shandy: "I will tell you in three words what the book is. - It is a history. - A history! Of who? what? where? when? Don't hurry yourself. - It is a history-book, Sir (which may possibly commend it to the world) of what passes in a man's own mind." (Tristram Shandy, vol. II, ch. 2). Since the novel's 27 sections make up one extended stream of consciousness detailing "what passes in [Johnson's] own mind" on one day, this highly apposite motto highlights two central observations: Firstly, as noted above, The Unfortunates is arguably more concerned with the elegist than with the deceased; secondly, it emphasises the centrality of thought processes and particularly of the workings of memory. Numerous passages detail, for instance, the way in which memory rearranges events based on spatial and temporal contiguity - "The mind is confused, was it this visit, or another, the mind has telescoped time here, runs events near to one another in place, into one another in time." ("Again the house" 4-5) - or retrospectively modifies assessments of situations, people or relationships based on later events: “[M]emories are not now of [Wendy] so much, but only of her in relation to him. So his death changes the past: yet it should not. Yet she too, Wendy, is changed in my mind by what happened later." ("Up there, yes" 1)

Similarly, he comments on the ethical impulse to embellish or sentimentalize remembrance, possibly because of the internalized notion of de mortuis nil nisi bene dicendum or to assuage one's own conscience: "I sentimentalize again, the past is always to be sentimentalized, inevitably, everything about him I see now in the light of what happened later, his slow disintegration, his death. The waves of the past batter at the sea defences of my sandy sanity, need to be safely pictured, still, romanticized, prettified." ("I had a lovely flat" 2)

Moreover, the narrator remarks on the mind's similarly self-protecting tendency to forget particularly poignant or painful moments in the compelling analogy of the "fuse" as a protective device against overvoltage or power surges: "Someone said, it must have been June, that there were times when Tony broke down, knew and said he would never live to see the boy grow up. I fail to remember, the mind has fuses." ("Then they had moved" 5)

Most importantly, however, the subdivision of the novel into unnumbered sections to be read in random order is clearly designed to suggest the non-linear, non-chronological and associative nature of memory. In his most sustained account of his own literary and critical beliefs, the 1973 "Introduction" to his prose collection Aren't You Rather Young to Be Writing Your Memoirs?, Johnson commented on 
this device as follows: "[A]nd all the afternoon I was there the things we had done together kept coming back to me as I was doing this routine job of reporting a soccer match: the dead past and the living present interacted and transposed themselves in my mind." (1985b [1973], 10) He goes on to specify the "main technical problem" faced in a novel that "was to be as nearly as possible a re-created transcript of how my mind worked during eight hours on this particular Saturday", namely the "randomness of the material", the interweaving of "the past and the present", which was "directly in conflict with the technological fact of the book: for the bound book imposes an order [...] on the material" (1985b [1973], 11).

It has been argued that Johnson's approach here should be regarded as inconsistent or insufficiently radical. Thus, Coe has maintained that "a longish, twelve-page section [...] would impose its own narrative sequence [and] any attempt at conveying randomness would be suspended for a good span of reading time” (1999, x). In her study on Chance and the Modern British Novel, however, Jordan plausibly defends Johnson's method as follows:

\footnotetext{
Memories and recollection of experience do not return to us in a linear, tightly plotted, traditionally novelistic way; but neither do they come to us as entirely disjointed flashes, or individual images. It is common enough to remember whole events and with them their significance, but not to remember these discrete entities in the correct, chronological order. Memories are not necessarily analogous to single words or even single sentences, but they are often episodic, and fragmented: much like the sections of The Unfortunates. $(2010,110)$
}

In one of the most perceptive discussions of The Unfortunates, Nicolas Tredell states that "the novel's topography of mourning and remembrance is urban and suburban" $(1985,40)$. Indeed, it is specifically the topography of the city which reminds the narrator of Tony, and it is memories of Tony that trigger memories of having visited Tony together with his former girlfriend Wendy, whose later betrayal was to be traumatic for him: "I even now forget what it was she betrayed me over, some other man, yes, but I have dealt with that, I do not have to think of that any more, it is past, why does Tony's death and this city throw them up at me again?" ("His dog” 5) Thus, palimpsestic layers of memory and their successive evocation are thematically and aesthetically central to the novel.

Despite its distinctly urban setting and the role of urban landmarks, places and spaces as crucial triggers of memory, The Unfortunates is, curiously, the only Johnson novel Philip Tew does not discuss (apart from a passing reference) in his chapter on "Cartography of Self and City" (2001, 167-206). A brief remark is enlightening, however: "For Johnson the personal, the pain, the subjective loss and its implications recur in space. He recalls visiting his now-dead friend and wife” (Tew 2001, 199-200). Benjamin's notion of urban memory as spatialized, layered, fragmented, disjointed, non-linear and ultimately hypertextual is helpful to conceptualize Johnson's representation of urban memory and its topographical anchoring (for the following, see my more detailed discussion in Gurr 2016). In the Arcades Project, Walter Benja- 
min develops a notion of the interpenetration of different layers of time and of their simultaneous co-presence in urban space, a phenomenon he refers to as "superposition” (1999, 172, 418, 854 et passim). Given a certain frame of mind - which Benjamin characterizes as that of the flâneur - this simultaneous co-presence can be perceived and understood by an urban observer. He even speaks of this "interpenetration and superposed transparency" of different times in a given space as the "perception of space [unique to] the flâneur" (1999, 546): “Thanks to this phenomenon, anything that ever potentially happened in a space is perceived simultaneously. Space winks at the flâneur: 'Well, whatever may have happened here?'” (1999, 418, translation modified; cf. also 4, 390, 392, 418, 462, 841, 854, 879f.). These parallels become even more persuasive if one bears in mind the similarities in the strategy of representation: The Arcades Project, Das Passagenwerk, is a vast collection of about 1000 pages of some 3500 quotations and thoughts on nineteenth-century Paris, organized into 36 folders or sections ("Konvolute") and a number of essays and outlines, proceeding not discursively, but by means of suggestive juxtaposition and montage. There are, for instance, multiple cross-references and some 30 different symbols marking thematic clusters across the different folders. This system of internal cross-references instead of a linear presentation strongly invites a kind of hypertextual reading following certain threads or thematic strands; Willi Bolle here speaks of a "network-like reading" (2010, 25; my translation). The non-linear representation both in the Arcades Project and in The Unfortunates is vital to the conceptualization of urban space as a space of layered, spatialized memory.

\subsection{Autobiography, 'Truth' and the Novel}

It is in the opening pages of his first novel, Travelling People, that Johnson formulated a conviction that was to remain central to his entire novelistic output:

Dr Johnson's remarks about each member of an audience always being aware that he is in a theatre could with complete relevance be applied also to a novel reader, who surely always knows that he is reading a book. [...] From this I concluded that it was not only permissible to expose the mechanisms of a novel but by doing so I should come nearer to reality and truth [...]. I realized it would be desirable to have interludes between my chapters in which I could stand back, so to speak, from my novel, and talk about it with the reader, or with those parts of myself which might hold different opinions [...] without any question of destroying the reader's suspension of disbelief, since such suspension was not to be attempted. (Johnson 1967 [1963], 11-12; gaps original)

The notion that any claim to 'truthfulness' requires anti-illusionist narrative strategies with Johnson sits oddly with - but for him is inseparable from - the notion that novelistic truth is only achievable by abandoning 'fiction' altogether and by limiting oneself to versions of autobiographical writing. Ryf even calls "the relationship 
between fiction and fact [...] the besetting issue of all Johnson's work” (1977, 63). In an unpublished interview with Bernard Bergonzi in 1968, Johnson stated: "I'm not interested in the slightest in writing fiction. [...] '[N]ovel' and 'fiction' are not synonymous. Certainly I write autobiography, and I write it in the form of a novel. What I don't write is fiction." (qtd. in Tew 2001, 84)

In keeping with this conviction, Johnson is frequently a character in his own novels - thinly disguised or even quite explicitly - in a way radically different from the way an author figure appears in, say, Fowles’ French Lieutenant's Woman ( $\nearrow 15 \mathrm{John}$ Fowles, The French Lieutenant's Woman). Thus, Johnson writes about family matters, financial worries, his supply teaching job, his jealousy, the frequency and (dis-)satisfactions of his lovemaking with Wendy, or the frustrations of having to write match reports to make a living:

Thank Christ I don't have to write that sort of preliminary speculative meaningless crap. Just my own kind of crap." ("Time” 2-3)

Now I must hack this into some shape, now I must make it into 500 well-chosen words. Yes, 500 they asked for. [...] Get on. $\quad$ By five. $\quad$ In 40 minutes. ("The pitch worn" 9; gaps original)

These self-representations include touchingly personal reflections: "Steven will be in bed, but I can still look at him sleeping, my son, the warmth of returning, to Ginnie, to our son, the flat will be lit as I come across the square" ("Last" 5). On other occasions, however, personal details can be embarrassingly revealing and make Johnson appear in a rather unfavourable light, as an egoist or undisciplined glutton. Thus, the realization that Tony's illness is serious comes when Tony and his wife June do not show up for the launch party of Johnson's first book, which was in fact, dedicated to them: "This shocked me, I was annoyed, angry even, that he, that both of them, should find any excuse whatsoever for missing something so important, that its importance to me should not be shared by them" ("Just as it seemed" 4). Similarly, "my response to insecurity is to eat, this is why I am overweight, no, fat, or so I persuade myself" (“Cast parapet” 1).

It is this specific mode of novelistic confessional writing and the concomitant unsparingness, it seems, that is alluded to in the choice of the last of the three mottos inside the box. This is again by Samuel Johnson, and, tellingly, is one attributed to him by his companion Boswell: "There is something noble in publishing truth, though it condemns one's self.” (Boswell 1970 [1785], 283)

\subsection{Writing and the Foregrounding of the Writing Process}

In keeping with Johnson's assertion - reiterated in self-reflexively paradoxical form within the novel - that "[i]n general, generalization is to lie, to tell lies" ("Last" 6), the scrupulous, halting and searching prose style does more than merely simulate 
the associative nature of a stream of consciousness. Rather, it also makes explicit the process of writing itself in that the frequent re-formulations within the individual sentence - frequently long, sprawling, associative clauses extending over more than half a page - and the numerous qualifications appear to increase specificity and precision:

And yes, there is a castle here [...] sandstone, as I remember [...] did Tony tell me, he had a great mind for such trivia, is that the right word, no, nor is detail, trivia it is to me, perhaps, to him important [...] he had a good mind for such detail, it crowded his mind like documents in the Public Records Office, there, a good image, perhaps easy, but it was even something like as efficient, tidy, his mind, not as mine is, random [...] how he embraced conversation, think of an image, no. [...] I learnt, I selected and elected to hear what I needed, what was of most use to me, at that time most use, from his discourse, yes, the word is not too pompous, discourse, a fine mind [...] how can I place his order, his disintegration? ("First" 3-4)

Jordan even speaks of an "excess of prosaic scrupulousness" and argues that each "sentence contains its own first - and sometimes second and third - draft" (2014, 746). It is characteristic of the self-reflexive nature of Johnson's prose that this tentative, iteratively self-corrective writing process is again made explicit in the novel itself, when the text refers to the process of "[w]orking more specifically, this time, on and around my first novel, discussing, improving, refining, deleting" ("Again the house” 1; cf. also Jordan 2014, 759). This is further supported by the unusual spacing throughout the text: frequent blanks far longer than the common single space after a full stop - often extending to half a line or more - also appear to suggest the halting nature of the prose style and apparently simulate pauses in thought or speech. Thus, the probing, searching, constantly self-correcting prose suits the attempt at 'truthfulness' while at the same time suggesting doubts that 'truth' is ever attainable. This, it seems, is hardly an accidental self-contradiction but rather seems a fully dialecticized tension that is central to the novel (cf. below 4.1). Moreover, this is a classic case of metalepsis, a blurring of ontological levels in that the same device - an associative, tentative prose style - is used to suggest, autodiegetically, the narrator's own reconstructed stream of consciousness and heterodiegetically, a writer-narrator's attempt at plausibly formulating such a stream: "The mind as a think of an image " ("The estate" 5; gaps original), or "no, the image is not right, does not help" ("Just as it seemed" 7). Similarly, several passages foreground the writer's need to extrapolate: "Why do I suppose all this from so little?" ("This poky lane” 7), highlighting the extent to which even the attempt at writing truthfully will necessarily involve a significant share of guessing, of making plausible assumptions. 


\section{Aesthetics: Narrative and Literary Strategies}

\subsection{Randomness and the "Book in a Box"}

Arguably more so than with most novels, the central narrative strategy of The Unfortunates, the subdivision into unnumbered sections to be read in random order, is inseparable from the key thematic concerns: cancer, memory or the city are all fundamentally characterized by randomness, unpredictability, non-linearity, proliferation and a resistance to formal representation. In formal terms, the novel thus continues and radicalizes the concern with typography and the materiality of the book. These, of course, were frequent concerns for Johnson throughout - the Shandean grey and black pages in Travelling People, the holes cut into some of the pages and the parallel columns of text in Albert Angelo, or the blank spaces and empty pages in House Mother Normal.

A fairly straightforward question arising from the frequent use of this device is that of chronology: Although there are technically a vast number of possible permutations - given 25 freely disposable sections, the result is the factorial of 25 (noted as 25 !), yielding just over $1.55 \times 10^{25}$ - not all of them make sense: The section in which the narrator watches the football match and writes his report must logically come after the section in which he makes his way to the stadium, just as it makes little sense to imagine him eating and contemplating his main course before he has had the starter of his lunch before the match. Nevertheless, the random order creates significant and often touching effects in the contemplation of the narrator's friendship with Tony and the progression of Tony's disease, for instance when the narrator recalls how Tony had for some time hoped he had been cured of cancer after we have already read about his death. The passage poignantly even has Tony "know" he has been cured:

Yet he knew by that autumn, when they had gone back to Chester, found a flat on the Wirral overlooking the sea and the Welsh mountains, ah, and had undergone more surgery, that he was cured, I think they told him he was cured, they must have, for I remember the letter I got from June, a separate one from him, too, that told me the news, the whole of the lump removed, June's letter ending in joy that the sun was shining across this view from their flat, on the mountains in the distance, on the sea, and that she could enjoy it, that she had a future again. ("Sometime that summer" 4)

Given this non-linear overlay of different points in time, Jordan rightly emphasises that “Tony's death is happening, has happened, will happen, palimpsestically" (2014, 755).

The representation of chance, randomness and contingency is thus central to Johnson's endeavour of 'truthfulness': "Life does not tell stories. Life is chaotic, fluid, random; it leaves myriads of ends untied, untidily. Writers can extract a story from life only by strict, close selection, and this must mean falsification. Telling stories really is 
telling lies.” (1985b [1973], 5). Randomness is thus arguably the overarching concern of the text and therefore needs to be discussed in some detail as a direct result of the novel's central device. Thus, a crucial passage, which, strictly speaking, only refers to Tony's disease, is highly suggestive for the novel as a whole: "the explosive, runaway, zealous, monstrous cells of the tumour: if one single cell escaped to another part of the body, by insinuating itself into the bloodstream, it would grow and multiply there too" ("Just as it seemed" 8). Beyond the proliferation of the tumour cells, it also suggests the non-linear, rhizomatic nature of the text, of memory, or of the city.

In her study on Chance in the Modern British Novel, Jordan's central tenet is her belief in "narrative's inability to be assimilated to chance, and chance's resistance to its own representation" $(2010,114)$. She plausibly argues that in the narrativization of life or of any other unpredictable, contingent process, the random is smoothed out and made to seem necessary $(2010,150)$. Referring to Leland Monk's study of the role of chance in Modernist British writing, she states that "chance always becomes fate in narrative" and speaks of "the steamroller power of a teleological narrative” (2010, 149):

[E]ventually, chance-as-subject-matter inevitably bursts through the inbuilt limitations of its own representation and engages directly with the form of the work, as a serious engagement with chance must confront the paradoxical nature of its representation in a determined form. The formal engagement of aleatorically experimental fiction is therefore an oblique commentary on chance's uniquely uncomfortable relationship to the literary forms that seek to contain it. $(2010,92)$

She further reads The Unfortunates as "aleatorical in the most fundamental sense [and] as perhaps the most serious attempt, at least in Britain, to engage with the problem of the representation of chance in the novel of the twentieth century" (2010, 109). She regards Johnson's strategy of representing chance by means of loose sections as "the only way that is genuinely, mimetically possible: by letting [chance] formally participate in the construction of the narrative" (Jordan 2010, 113). This, however, seems clearly misleading in that it does not distinguish between aleatory processes of production and reception. Johnson's strategy is markedly different from, say, William Burroughs's cut-up or fold-in techniques: While Burroughs incorporates chance into the process of production, this is precisely not the case with Johnson's strategy, which relies on randomness on the reception side.

\subsection{Literary References, Traditions and Convictions: From the Augustans to the nouveau roman}

Though he explicitly rejected the category of 'experimental' writing as a description of his work, arguing that "experiments" are merely attempts at "solving particular writing problems” (1985 [1973], 8), Johnson inscribes himself into a fairly specific, 
frequently 'experimental' tradition, in which Laurence Sterne features prominently, beginning with the typographical devices and the black and grey pages in Travelling People and extending to the motto in the box in The Unfortunates.

Moreover, there appears to be an alignment with a Modernist and late-Modernist tradition, Joyce and Beckett being his celebrated models (cf. Johnson 1985 [1973], 4, 7, 入 7 James Joyce, Ulysses, $\nearrow 12$ Samuel Beckett, Molloy, Malone Dies and The Unnamable). Furthermore, although his political convictions could not be further from Eliot's and although Eliot's elitism would seem to have been entirely alien to Johnson, his assessment of twentieth-century history and contemporary reality, as well as the conclusions for literary practice he draws from it, are remarkably similar: His belief that "what characterises our reality is the probability that chaos is the most likely explanation" (1985b [1973], 7) is strongly reminiscent of Eliot's view of "contemporary history" as an "immense panorama of futility and anarchy” in his 1923 essay "Ulysses, Order, and Myth" (Eliot 1975, 177). Given this diagnosis, both Eliot and Johnson apparently share the assumption that "to find a form that accommodates the mess, that is the task of the artist now", as Johnson approvingly quotes Beckett in his programmatic “Introduction” to Aren't You Rather Young to Be Writing You Memoirs (1985b [1973], 7).

As more direct influences on The Unfortunates, one can identify Beckett's prose fiction (for the sprawling, associative prose), or, for the concern with the aleatory and the materiality of the book, Alan Burns' cut-up text Babel (1969), Julio Cortázar's Hopscotch (1966), Marc Saporta's Composition No. 1 (1962) as a previous "book in a box" (for a comparison, cf. Coe 2004, 231), Raymond Queneau's Cent mille milliards de poèmes (1961) and the contemporary French nouveau roman of Alain Robbe-Grillet or Nathalie Sarraute (cf. Jordan 2010, 93-94, or Levitt 1981, 579). Parallels in terms of aesthetic concerns and literary strategies can be identified with the work of Doris Lessing or of John Fowles, whose The French Lieutenant's Woman was also published in 1969, and with other contemporaries like Rayner Heppenstall and Eva Figes, who were part of Johnson's circle of “experimental” writers ( $~ 14$ Doris Lessing, The Golden Notebook, $\pi 15$ John Fowles, The French Lieutenant's Woman).

However, counter-intuitively, classicist writers of the eighteenth century also play a considerable role. The references to his namesake Samuel Johnson and his biographer Boswell - which, though Johnson was notably invoked in Travelling People already (cf. above 2.4), are particularly prominent in The Unfortunates - are probably largely due to the biographical constellation and the role Johnson plays as Tillinghast's Boswell, as it were. Similarly, the reference to another Augustan poet is functional in a very specific way, apart from the fact that "Alexander" as a footballer's name may simply have suggested the allusion. Bored with the game and with the report he is writing, Johnson entertains himself by contriving to sneak literary allusions into his match report: 
Devoid of real incident, the match dragged its slow length, no, yes, there's Alexander, earlier, when he hit the bar. Alexander, dragging his slow length along from right back, hit a long one which beat Phipps but struck the intersection, like a wounded snake has to be worked in somewhere, no, it'll never work, too contrived, scrub it. (“The pitch worn" 6; italics original)

The reference is of course to Alexander Pope's "Essay on Criticism” (1711) and its self-reflexive performative critique of the tedious writing of inferior poets:

A needless Alexandrine ends the Song

That like a wounded Snake, drags its slow length along. (1963, 11. 356-357; italics original)

The "Essay on Criticism" - although a work of the very young Pope - is inseparable from Pope's own poetic practice and is concerned with a type of criticism that seeks to censure bad poetry in order to enable the writing of better poetry rather than with criticism as an art of its own. This is very much in line with Johnson's own views on the function of criticism as expressed in a debate with Tony: "[W]e argued almost viciously about criticism. To Tony, the criticism of literature was a study, a pursuit, a discipline of the highest kind in itself: to me, I told him, the only use of criticism was if it helped people to write better books" ("The opera singer" 1). Thus, references to individual writers outside an 'experimental' tradition can generally be shown to have specific thematic implications, whereas references to the 'experimental' tradition frequently serve the self-positioning as a writer.

All in all, "Johnson extends modernist experimental techniques, radicalising them by subverting what he regards as High-Modernist elitism” (Tew 2012, 55). The novel's narrative strategies and the explicit or implicit references to other writers place Johnson firmly in an experimental tradition of a decidedly non-elitist type, making him a figure who can plausibly be claimed both for a late-modernist and for an early postmodernist phase.

\section{Reception and Theoretical Perspectives}

\subsection{Reception}

The tension of 'truth vs. experiment' appears to have overshadowed the novel's reception from the beginning. In addition to a number of appreciative reviews, several initial responses were belittling: The Observer reviewer Stephen Wall called The Unfortunates "a little experiment" with "a mild logic of its own" and spoke of "a modest, sincere, small-scale novel” (qtd. in Coe 2004, 269), while Richard Holmes in The Times argued that the novel's "technical self-absorption" deprived the characters of any "reality" and prevented any interest in them (qtd. in Coe 2004, 269). 
In his 1970 study The Situation of the Novel, Bernard Bergonzi commented on Johnson's convictions and the concomitant self-limitations as follows:

The idea that fiction is lying, and in other respects undesirable, has been propagated by another English novelist, B.S. Johnson, whose considerable talents seem to me to be unnecessarily limited by his doctrinaire attitudes. For an English writer Johnson is remarkably conscious and theoretical in his ideas about what he wants to do. (Bergonzi 1970, 204; also qtd. in Tew 2001, 9)

In 1973, a TLS reviewer pithily commented on the dominant impression that a more compelling book for Johnson "seems to be just round a corner which he doctrinally refuses to turn” (qtd. in Ryf 1977, 73), while Patrick Parrinder in 1977 similarly stated that Johnson was frequently "seen as a brilliant writer thrashing around in a trap of his own making” $(1977,45)$.

In a 1985 memoir cum assessment for a special issue of The Review of Contemporary Fiction, Johnson's friend and fellow experimentalist Eva Figes commented on his achievements and limitations and, despite what now seems a generally more positive view of Johnson's achievements, in many ways formulates the persisting doubts about his self-limiting insistence on autobiographical truth:

[H]e created [literary texts] about real people, real experiences and events, with himself as undisguised narrator and main character. This could be witty and delightful, but at other times a bit ponderous. He had a tendency to take things to extremes, to take truth-telling too literally [...]. I think he worked himself into a cul-de-sac. [...] By concentrating too much on form, on literal truth, I think Bryan lost touch with an essential, greater truth - that the only way to tell the truth is by lying, and that is the real starting point of meaningful fiction. $(1985,71)$

Since the 1990s, the two major champions of Johnson's work and arguably the driving forces behind the modest but perceptible revival of critical interest have been Philip Tew, the author of the first major monograph on Johnson (2001), and Jonathan Coe, the author of a highly original and sympathetic biography (2004); in addition to their monographs, both have helped rekindle interest in Johnson with perceptive essays, introductions to and reviews of novels reissued after having been out of print since the time of Johnson's death. Both have championed Johnson as an immensely talented and original writer (despite his self-imposed limitations), who almost singlehandedly opposed the neo-realist mainstream with a sequence of experimental novels, of which The Unfortunates is often regarded as the most compelling and most innovative one. In sum, Johnson is generally regarded as an enormously gifted writer whose stubborn convictions amounted to a self-restriction as essentially a writer of memoirs, forcing him into increasingly remote parts of his family history and, in his last novels, strained rather than persuasive literary experiments. 


\subsection{Contradiction, Paradox and Narrative}

It has long been shown that narrative proceeds from binary oppositions (by, for example, Greimas, Lotman and Todorov) and that it is based on the acting out, on the "mise en branle" (Greimas 1970, 164), of underlying dichotomies. In that sense, narrative is always already as narrative a way of dealing with binary oppositions. This quality of narrative might also be conceptualized in terms of Žižek's notion that "narrative as such emerges in order to resolve some fundamental antagonism by way of arranging its terms into a temporal succession. It is thus the very form of narrative which bears witness to some repressed antagonism" (1999, 197; italics original). It is equally established that narrative is a way of negotiating, even of harmonizing, oppositions and contradictions that could not be reconciled discursively (for an insightful collection exploring the potential of fiction in the negotiation of extremes, cf. Glomb and Horlacher 2004). It is less clear, however, how contradictions between ideology and form, genre conventions and modes of emplotment or between illusionist and anti-illusionist narrative strategies within a narrative text are to be conceptualized and it is precisely these tensions and potential contradictions that critics have diagnosed in Johnson's work and particularly in The Unfortunates (cf. especially Mackrell 1985). Judith Mackrell's discussion raises the question whether these are productive ambiguities or problematic contradictions when she argues that Johnson's insistence on form "seems to serve two different functions: on the one hand, Johnson appears to be genuinely examining their different mimetic possibilities; on the other hand, he may frequently overplay a form or style in order to expose it as a literary artifice" $(1985,45)$. While this may sound like a productive tension, her diagnosis of an "alternating commitment to a painstaking form of mimesis and a radical denial of the mimetic" (58), by contrast, suggests a rather fundamental unresolved contradiction. Similarly, Tew points out the uneasy connection between Johnson's anti-illusionist experimentalism and his claim to "truth", quoting Gabriel Josipovici to the effect that "experimental fiction's overriding impulses reject verisimilitude and counter any illusion of the real" (Tew 2012, 53).

Similar tensions might be observed between Johnson's focus on interiority and his inclination towards class-conscious littérature engagée, the solipsistic insistence that the only relevant subject matter may be "the inside of his own skull" (1985b [1973], 4) being curiously at odds with his frequently political bent (though this is largely absent in The Unfortunates). Finally, the genre of the elegy can be said to jar with the non-linearity of the text: While the elegy teleologically moves from grief and mourning to consolation, precisely this development is subverted and consolation made impossible by the fundamental non-linearity of the text (cf. also Jordan 2014, 748).

Admitting that his convictions about order and structure "and other things I have said [...] must appear paradoxical”, Johnson polemically asks: "But why should novelists be expected to avoid paradox any more than philosophers?” (1985b [1973], 7) 
It might even be argued that such tensions and contradictions are crucial to Johnson's novelistic production. Thus, Jonathan Coe has argued that “if Johnson's work stands up better today than most of the writing of his 'experimental' peers, this has everything to do with the fact that he refused - or was unable to - sacrifice intensity of feeling on the altar or formal ingenuity" $(2004,29)$. The parenthesis, "or was unable to", of course, tellingly points to just the central tension we are concerned with, suggesting that the continuing narrative interest his novels generate may have been more of an accident and occurs against his stated aims: Denouncing the "primitive, vulgar and idle curiosity of the reader to know 'what happens next"', he did maintain that to even attempt to satisfy it "must be a confession of failure on the part of any novelist" (Johnson 1985b [1973], 5).

Johnson was not alone, however, in exploring how the use of metafiction and other anti-illusionist devices relate to narrativity and narrative 'curiosity'. In an essay first published in 1976, J. M. Coetzee remarked that metafictional devices can never obliterate the narrative impetus: "[T]ranscendence of the illusionism of Realism is an illusionary hope [and] to get behind (aufheben) fiction by incorporating into fiction a critical consciousness of the procedures of fiction is only to climb another spiral of illusionistic Realism [...]” (1976, 92; parenthesis original; for the inescapability of narrative behind even the most obtrusive metafictional devices, cf. also Lehmann 1986).

While one may well find Johnson's insistence on literal autobiographical truth a misguided self-limitation, it hardly seems plausible to argue that these and other tensions in his work are unresolved contradictions he was unaware of. Rather, such tensions and contradictions seem fully dialecticized in an œuvre which, like that of hardly any other writer, self-consciously explores the functions, potentials and limitations of narrative.

\subsection{Media Evolution and the Place of the Novel}

Johnson formulates his program of writing truthful, introspective, non-narrative novels with a clear view to the role of the novel in a new media environment. Based on the insight that film and TV have become the privileged media for storytelling in the way that had previously been the domain of the novelist, he drastically argues that the "nineteenth-century narrative novel" was dead and that to continue trying to write it was "anachronistic, invalid, irrelevant, and perverse" (1985b [1973], 5). This leads him to a redefinition of what it is that the novel is best capable of doing and what its function and purpose can and should be:

No novelist's description of a battle squadron at sea in a gale could really hope to compete with that in a well-shot film; and why should anyone who simply wanted to be told a story spend all his spare time for a week or weeks reading a book when he could experience the same thing in a version in some ways superior at his local cinema in only one evening? [Just as the days 
of long narrative poems were over when the novel became the privileged medium, but poetry survived by] concentrat[ing] on the things it was still best able to do [...], the novel may not only survive but evolve to greater achievements by concentrating on those things it can still do best: the precise use of language, exploitation of the technological fact of the book, the explication of thought. [...] In some ways the history of the novel in the twentieth century has seen large areas of the old territory of the novelist increasingly taken over by other media, until the only thing the novelist can with any certainty call exclusively his own is the inside of his own skull: and that is what he should be exploring, rather than anachronistically fighting the battle he is bound to lose. (Johnson 1985b [1973], 4)

The telling of plot-driven stories, Johnson clearly argues, is best left to other media. Therefore, if the materiality of the book and the representation of mental processes are to be central to novelistic production, then the inextricable combination of both a radical use of the former to do justice to the randomness of the latter - seems the logical way forward for the novel. In that sense, The Unfortunates is certainly Johnson's definitive novel. Most critics, however, have regarded the self-imposed limitation to autobiography and the insistence that a novel must be 'true' in a narrow factual-biographical sense as a dead end. With precisely this biographical focus, however, Johnson's work appears to have anticipated the more recent vogue of confessional and memoir writing generally, as well as, more specifically, the numerous memoirs of disease, death and loss such as those by Ruth Picardie, John Diamond, Joan Didion and others, to mention only a few of the more widely read texts of this kind in the last 20 years (for this, cf. Tew 1999, xv).

\section{Bibliography}

\subsection{Works Cited}

Johnson, B. S. The Unfortunates. London: Picador, 1999 [1969].

$---$

Benjamin, Walter. The Arcades Project. Trans. Howard Eiland and Kevin McLaughlin. Cambridge: The Belknap Press of Harvard University Press, 1999.

Bergonzi, Bernard. The Situation of the Novel. London: Macmillan, 1970.

Bolle, Willi. “Metropole \& Megastadt: Zur Ordnung des Wissens in Walter Benjamins Passagen." Urbane Beobachtungen: Walter Benjamin und die neuen Städte. Ed. Ralph Buchenhorst and Miguel Vedda. Bielefeld: transcript, 2010.17-51.

Boswell, James. “Journal of a Tour to the Hebrides with Samuel Johnson, LL.D.” Johnson's Journey to the Western Islands of Scotland and Boswell's Journal of a Tour to the Hebrides with Samuel Johnson, LL.D. Ed. R. W. Chapman. London/Oxford/New York: Oxford University Press, 1970 [1785]. 151-447.

Coe, Jonathan. "The Novels of B. S. Johnson." The Spectator, 24 August 1991: 28-29.

Coe, Jonathan. "Introduction." B. S. Johnson. The Unfortunates. London: Picador, 1999. v-xv.

Coe, Jonathan. Like a Fiery Elephant: The Story of B. S. Johnson. London: Picador, 2004. 
Coetzee, J. M. “The First Sentence of Yvonne Burgess' The Strike." Doubling the Point: Essays and Interviews. Ed. David Attwell. Cambridge: Harvard University Press, 1992 [1976]. 91-93.

Eliot, T. S. “Ulysses, Order, and Myth.” Selected Prose of T. S. Eliot. Ed. Frank Kermode. London: Faber and Faber, 1975 [1923]. 175-178.

Figes, Eva. "B. S. Johnson." Review of Contemporary Fiction 5.2 (1985): 70-71.

Garrett, George P. “B. S. Johnson.” Poets of Great Britain and Ireland Since 1960, Part 1: A-L; Part 2: M-Z. Ed. Vincent. B. Sherry. Ann Arbor: Gale, 1985. 277-282.

Glomb, Stefan, and Stefan Horlacher, eds. Beyond Extremes: Repräsentation und Reflexion von Modernisierungsprozessen im zeitgenössischen britischen Roman. Tübingen: Narr, 2004.

Greimas, Algirdas J. “Eléments d'une grammaire narrative.” Du sens: Essays sémiotiques. Paris: Editions du Seuil, 1970. 157-183.

Gurr, Jens Martin. "The Modernist Poetics of Urban Memory and the Structural Analogies between 'City' and 'Text': The Waste Land and Benjamin's Arcades Project." Recovery and Transgression: Memory in American Poetry. Ed. Kornelia Freitag. Newcastle: Cambridge Scholars Publishing, 2015. 21-37.

Johnson, B. S. Travelling People. London: Panther, 1967 [1963].

Johnson, B. S. Christie Malry's Own Double-Entry. New York: New Directions, 1985a [1973].

Johnson, B. S. "Introduction to Aren't You Rather Young to Be Writing You Memoirs." Review of Contemporary Fiction 5.2 (1985b) [1973] [Special Issue on B. S. Johnson]: 4-13.

Johnson, B. S. B. S. Johnson Omnibus (Albert Angelo, Trawl, House Mother Normal). London: Picador, 2004.

Johnson, Samuel. "The Rambler, No.60, Saturday, 13 October 1750" ["The dignity and usefulness of biography"]. The Yale Edition of the Works of Samuel Johnson. Vol. III. The Rambler. Ed. W. J. Bate and Albrecht B. Strauss. New Haven: Yale University Press, 1969. 318-323.

Jordan, Julia. Chance and the Modern British Novel: From Henry Green to Iris Murdoch. London: Continuum, 2010.

Jordan, Julia. “'For recuperation': Elegy, Form, and the Aleatory in B. S. Johnson's The Unfortunates." Textual Practice 28.5 (2014): 745-761.

Kraushaar, Katja. Englische Elegien: Versuche der poetischen Selbstvergewisserung englischer Dichter in ihrer Auseinandersetzung mit dem Tod. Frankfurt/Berlin: Peter Lang, 2004.

Lea, Daniel. "Narrative Wreckage: Cancer and the Unfortunate Body in B. S. Johnson." English Studies 96.7 (2015): 785-798.

Lehmann, Elmar. “'Ha et cetera.' Oder: Von der Unmöglichkeit, nicht zu erzählen: Überlegungen zu englischen Ich-Romanen der 80er Jahre." Gattungsprobleme in der anglo-amerikanischen Literatur: Beiträge für Ulrich Suerbaum zu seinem 60. Geburtstag. Ed. Raimund Borgmeier. Tübingen: Niemeyer, 1986: 184-194.

Levitt, Morton P. "The Novels of B. S. Johnson: Against the War Against Joyce." Modern Fiction Studies. 27.4 (1981): 571-586.

Levitt, Morton P. “B. S. Johnson.” British Novelists Since 1960: Part 2: H-Z [DLB 14]. Detroit: Gale, 1983. 438-444.

Mackrell, Judith. "B. S. Johnson and the British Experimental Tradition: An Introduction." Review of Contemporary Fiction 5.2 (1985): 42-64.

Monk, Leland. Standard Deviations: Chance and the Modern British Novel. Stanford: Stanford University Press, 1993.

Parrinder, Patrick. “Pilgrim's Progress: The Novels of B. S. Johnson (1933-1973)." Critical Quarterly 19.2 (1977): 45-59.

Pope, Alexander. "An Essay on Criticism.” The Poems of Alexander Pope. Ed. John Butt. London/New York: Routledge, 1963.143-168.

Ryf, Robert S. “B. S. Johnson and the Frontiers of Fiction.” Critique 19.1 (1977): 58-74. 
Sacks, Peter M. The English Elegy: Studies in the Genre from Spenser to Yeats. Baltimore: Johns Hopkins University Press, 1985.

Shustermann, Ronald. "Leafing Through a Universe: Architectural Bodies and Fictional Worlds." Architecture and Philosophy: New Perspectives on the Works of Arakawa and Madeline Gins. Ed. Jean-Jacques Lecercle and Françoise Kral. Amsterdam/New York: Rodopi, 2010. 169-187.

Sterne, Laurence. The Life and Opinions of Tristram Shandy, Gentleman. Ed. Ian Watt. Boston: Houghton Mifflin, 1965 [1759-1767].

Tew, Philip. B. S. Johnson: A Critical Reading. Manchester/New York: Manchester University Press, 2001.

Tew, Philip. "Moving Beyond Modernism in the Fiction of B. S. Johnson: Charting Influences and Comparisons." The Legacies of Modernism Historicising Postwar and Contemporary Fiction. Ed. David James. Cambridge: Cambridge University Press, 2012. 53-71.

Tredell, Nicolas. "Telling Life, Telling Death: The Unfortunates." Review of Contemporary Fiction 5.2 (1985): 34-42.

Žižek, Slavoj. "The Seven Veils of Fantasy." Key Concepts of Lacanian Psychoanalysis. Ed. Danny Nobus. New York: Other Press, 1999. 190-218.

\subsection{Further Reading}

Coe, Jonathan, Philip Tew, and Julia Jordan, eds. Well Done God! Selected Prose and Drama of B.S. Johnson. London: Picador, 2013.

Jordan, Julia, and Martin Ryle, eds. B. S. Johnson and Post-War Literature: Possibilities of the Avant Garde. Houndmills: Palgrave, 2014.

Tredell, Nicolas. Fighting Fictions: The Novels of B. S. Johnson. Nottingham: Paupers' Press, 2000. You're Human Like the Rest of Us: The Films of B. S. Johnson. DVD/Blue Ray. London: British Film Institute, 2013. 


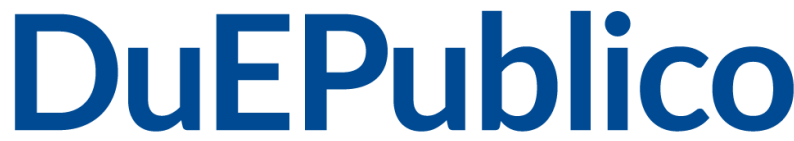

Duisburg-Essen Publications online offen im Denken

Ub $\begin{aligned} & \text { universitäts } \\ & \text { bibliothek }\end{aligned}$

This text is made available via DuEPublico, the institutional repository of the University of Duisburg-Essen. This version may eventually differ from another version distributed by a commercial publisher.

DOI: $\quad 10.1515 / 9783110369489-017$

URN: urn:nbn:de:hbz:464-20210312-110603-9

Gurr, Jens Martin. "B. S. Johnson, The Unfortunates (1969)". DOI: https://doi.org/10.1515/9783110369489-017

In: Handbook of the English Novel of the Twentieth and Twenty-First Centuries, edited by Christoph Reinfandt, Berlin, Boston: De Gruyter, 2017, eISBN: 9783110369489.

DOI: https://doi.org/10.1515/9783110369489 pp. 323-343.

(C) 2017 Walter de Gruyter GmbH, Berlin/Boston. All rights reserved. 